\title{
SYRIAN REFUGEES IN TURKEY: \\ Implementation of Turkey Open Door Policy in Dealing with Syrian Refugees
}

\section{Muhammad Fawwaz Syafiq Rizqullah, Fadhillah Jofianta Putri, Shania Afridita, Halim Purnomo}

Universitas Muhammadiyah Yogyakarta, Indonesia

email:syafiqrizqullah@gmail.com,fadhilahjofiant@gmail.com,shaniaafr@gmail.com,

\author{
halimpurnomo@umy.ac.id
}

Received: May 14, 2020 | Revised: July 15, 2020 | Approved: August 18, 2020

\begin{abstract}
The Syria refugees' problems in the Middle East with most of the victims are Muslim is the humanitarian cases which still cannot be fixed until nowadays. In order to response that problems Turkey government which has majority society are Muslim and supported by the geographical location because Turkey has located nearby Syria take action and created policy to support Syria refugees in order to help their life. However, the aim of this paper is to puzzle out the Turkey aim in implementing the open-door policy by Turkey government under president Recep Tayyip Erdogan. By using Regime theory by qualitative research method based on journal, book, and other credible resource. This paper find out several if there is some reason behind why Turkey implementing the policy toward Syria refugees there are first, become the reason to enter as the full members of EU, second, in order to gain bargaining position and lifting the name of Turkey as the country who care about humanitarian cases in international scale, and third as the evidence of Turkey if Turkey has ratifying the UN convention on human right. This paper also explains about how Turkey action in facilitating the Syria refugees and try to protect their right and life. And lastly, this paper also gives information about challenging that Turkey dealing in implementing this policy to help the Syria refugees.
\end{abstract}

Keywords: Syrian Refugees; Open Door Policy; Turkey

\begin{abstract}
Abstrak
Permasalahan pengungsi Suriah di wilayah Timur Tengah yang mayoritasnya beragama Islam adalah permasalahan kemanusian yang sampai saat ini belum dapat terselesaikan. Pemerintah Turki sebagai negara yang juga mayoritas masyarakatnya muslim dan letak geografisnya berdekatan dengan Suriah mengambil langkah dan kebijakan untuk membantu menyelesaikan permasalahan pengungsi tersebut. Dalam paper ini penulis mencoba untuk meneliti terkait motivasi di balik kebijakan "open door policy" yang diimplementasikan oleh pemerintah Turki di bawah kepemimpinan Presiden Recep Tayyip Erdogan. Dengan menggunakan teori Regime dan pendekatan
\end{abstract}


metode kualitatif yang bersumber pada jurnal, buku dan sumber yang bersifat kredible lainnya maka paper ini menemukan bahwasannya ada beberapa alasan yang mengantarkan Turki menerapkan kebijakan tersebut diantaranya adalah sebagai alasan untuk bisa menjadi anggota EU, mengangkat nama baik Turki di skala Internasional dan juga mengimplemntasikan kepedulian terhadap permasalahan kemanusiaan dan bentuk retifikasi terhadap konvensi PBB dalam permasalahan migrasi terpaksa. Selain itu paper ini juga menjelaskan bagaimana aksi yang dilakukan Turki dalam memfasilitasi para pengungsi Suriah dan juga menjelaskan terkait bagaiaman kendala - kendala yang di dapatkan oleh Turki baik dari luar maupun dalam Turki dalam menerima para pengungsi tersebut.

Kata Kunci: Pengungsi Suriah;Kebijakan Terbuka; Turki

\section{Introduction}

The flow of human movements has continued throughout history. But until now, the discussion on aspects of migration remains a challenge. The issue of refugees is an issue that takes a lot of public attention because the number continues to increase and requires special attention. Syria, being one of the countries with the largest refugees in the world, this is due to the consequences of conflict in the country. Syria which has the full name Syrian Arab Republic (Syrian Arab Republic / Al-Jumhūriyyah al-'Arabiyyah al-Sūriyyah / السورية العربية الجمهورية) is a country located in western Asia precisely in the levant region in the Middle East which has an area of $185.180 \mathrm{~km} 2$ and directly borders Turkey in the north, Iraq in the east, the Mediterranean Sea and Lebanon in the west, and Jordan and Israel in the south (kemlu.go.id).

Tensions between Turkey and Syria arose after the Arab Spring broke out in Middle Eastern countries. Opposition by Syrian rebels against the regime that led the Bashar Al-Asad regime caused many damage and casualties. This makes Turkey also feel the direct impact. Turkey was harmed by the Syrian conflict which caused security instability as well as a wave of refugees that put pressure on the Turkish economy. In the end Turkey supported the Syrian rebel forces in order to bring down the regime. The outbreak of the Syrian conflict also made Turkey cut off its diplomatic relations with Syria. On March 26 Turkey closed its embassy in Damascus Syria. This closure was triggered by bombings and massacres that took place in the city of Homs which took many lives. Turkey also expelled the Syrian ambassador in Turkey on May 30, 2012. Expulsion by Turkey caused by the massacre that occurred in Syria Houla. (Suri, 2019) 
The Syrian conflict began in the Arab Spring that spread to Syria. The wave of "The Arab Spring" is a wave of civil uprisings against the power of government in Arab countries that tend to be authoritarian. A wave of civilians demanding the opening of democratic taps hit almost all countries in the Arabian Peninsula, which began in Tunisia and Egypt in 2010, and immediately hit the Syrian state led by Bashar Al-Assad (Sumaryati, 2016). In Syria, the beginning of the Arab Spring began on March 6, 2011, when a group of children in Deraa Province made a graffiti that read "as-shaab yoreed eskaat elnizam" (people want to overthrow the regime) (Syukran \& Ubaidullah, 2019). The 15 children who were thought to be involved in making graffiti were detained by the police and tortured in prison, resulting in the anger of parents whose children were arrested and residents. This is the beginning that is the cause of anti-regime demonstrations. Initially only addressed to the Governor of the City of Deraa (Faisal Khaltoum), but the government considered this was an act of defiance against the regime and responded to the demonstration by means of repressive means of shooting tear gas, rubber bullets and even live ammunition which caused fatalities to forcefully disperse the action demonstration. Initially the demands of the demonstrators were only to free the children who were captured, but when the government carried out violence against the demonstrators finally the demands became widespread to bring down the ruling regime. The escalation of the demonstration has not only spread in Dera, but has also begun to spread to other cities in Syria (Kuncahyono,2013: 115-116).

Since March 2011 this conflict has claimed many victims, thousands of refugees, and thousands of children have been orphaned by the loss of their parents. Thousands of houses, infrastructure and public facilities were destroyed. When Bashar Al-Assad's regime became more repressive and cruel to kill people who were considered rebellious, resulting in almost half of the Syrians fleeing to various countries and most to the country of Turkey (Soekanto, 2016).

The impact of the Syrian conflict has reached an increasingly alarming stage, not only for Syrians who are forced to flee, but also has caused its own problems in neighboring countries. According to data obtained in April 2014, around 6.5 million Syrians have left their homes due to prolonged conflict (Huber \& Reid, 2014). Since March 2011, 2.7 million Syrians - or around 10 percent of the total population in the country - have fled to neighboring countries. At the end of 2014, the number of Syrian 
refugees is expected to reach 4.1 million. Since September 2013, UNHCR (United Nations High Commissioner for Refugees) has designated at least 2 million Syrians as refugees in four of its neighbors, namely Jordan, Iraq, Lebanon and Turkey. Hundreds of thousands more live outside the region without access to international assistance (Fahham \& Kartaatmaja, 2014). In 2016, the United Nations (UN) identified 13.5 million Syrian citizens in need of humanitarian assistance, of which more than 6 million were refugees in Syria, and more than 4.8 million were refugees outside Syria. Turkey is the largest holding country with more than 2.7 million Syrian refugees. While the most recent data in February 2020 recorded the number of Syrian refugees reached around 3.6 million people (UNHCR, Syria Regional Refugee Response, 2020).

The open door policy is part of the Turkish New Law LFIP, which refers to the Geneva agreement (Geneva Convention 1951) on Refugee Status on July 28, 1951, then amended in 1967 to become the Protocol on Refugee Status (Amalia, 2018) . Before the open door policy, the Turkish government did not receive a large influx of refugees, foreigners who wanted to enter Turkish territory through the border must have a passport and visa, and for refugees who are in the border region must go through several processes to be able to enter Turkish territory (Kibar, 2013). Before the LFIP policy was issued, Turkey accepted Syrian refugees only as 'guests' because based on the principle of fellow brothers and sisters, guests in this case means that the status and right to live in Turkey is not yet clear. Finally in 2013 after negotiating with the European Union, Turkey issued an Open Door Policy based on the requirements submitted by Turkey against the European Union, one of the conditions was the responsibility of the European Union to provide financial assistance as a substitute because EU countries refused to accept waves greater refugee (Simsek, 2017). After the agreement with the European Union was agreed upon, the Turkish New Law was issued and used as a guideline by the Turkish government to date in dealing with Syrian refugees in Turky.

Turkey's policy of continuing to open doors for Syrian refugees has placed Turkey as the world's most refugee holding country. especially in 2015, Turkey accommodated around 2,503,549 Syrian refugees and in 2016 as many as 2,970,000 Syrian refugees were registered officially in Turkey. Turkish policy that continues to open the border door to the Syrian refugees apparently not owned by other Arab countries, including countries in the European Union (Sari, 2017). 
Based on the background statement, this paper will discuss further about, (1) the reason why Syrian refugees decide Turkey as their destination, (2) the Turkey action in accepting Syrian refugees, (3) the advantages of Turkey government in accepting Syrian refugees, and (4) the challenges for the Turkey Government in accepting the refugees.

\section{Theoretical Framework}

In this paper the author using Regime Theory by Krasner to analyze the opendoor policy which implemented by the Turkey Government under Erdogan administration. The definition of regime theory by Krasner is International regime are defined as principles, norms, rules, and decision-making procedures around which actors' expectations converge in each issues area (Simmons, 1987). In the others side the International regime is something agreement by several countries in the world and commonly accommodate by the supreme authority for the example the International Organization like United Nation (UN) which it regulation can determine and influence the state behavior in term of implementing some public policy or foreign policy. however, this theory is appropriate to analyze the policy which created by some country and for some purpose because it always because of some factors and actors behind who influence the state behavior in take some decision.

By using Regime theory, the author would like to understand why Turkey Foreign policy under the Erdogan Administration would like to implement the opendoor policy in accepting the refugees from the Syria. In term of economic or political advantages the Turkey government will not get any big advantages in order to accepting and facilitating the Syrian refugees. It became interesting paper because Turkey as one of the countries who accepting highest refugees in the world compare with others state in European Union (EU). Turkey also in accepting the refugees dealing with a lot of challenge from inside and outside of Turkey but under Erdogan Administration Turkey still stick with the policy even in current situation Turkey still endeavor to open special place near by Syria to become the refugees camp (USTUN, 2015). However, in this paper will explain specifically why Turkey done with this policy and what is the fundamental factors which drive Turkey to implementing this policy toward the refugees from Syria and what is the benefit or the advantages which Turkey got by helping a lot of refugees who's decided leaving to Turkey as the country destination. 


\section{The Reason Why Syrian Refugees Decided to Make Turkey as Their Destination}

In 2014, Turkey became the number one of refugee receiving country and in 2010s was a period where high numbers of refugees arrived in Turkey. Based on the statistics data from UNHCR, in 2014 Turkey received 1,587,374 people, mid 2015 1,838,848 people, and in mid 2016 2,869,421.(The United Nations High Comissioner for Refugees (UNHCR), 2018). Meanwhile in 2019, what so called Turkey refugee breakdown, was from neighbors country with the most data is from Syrian 3.6 M, Iraqis 142,000, Iranians 39,000, Afghans 172,000, and Africa 11,700.(UNHCR, 2018). Based on the report from UNHCR in 2018, Turkey hosted $63.4 \%$ of all the registered syrian refugees and in February 27, 2020, refugees from Syria because of the Syrian Civil war, was 3,587,266. (UNHCR). However, The Turkey become the Country who accepting the Syria refugees the most and can we see with the maps below:

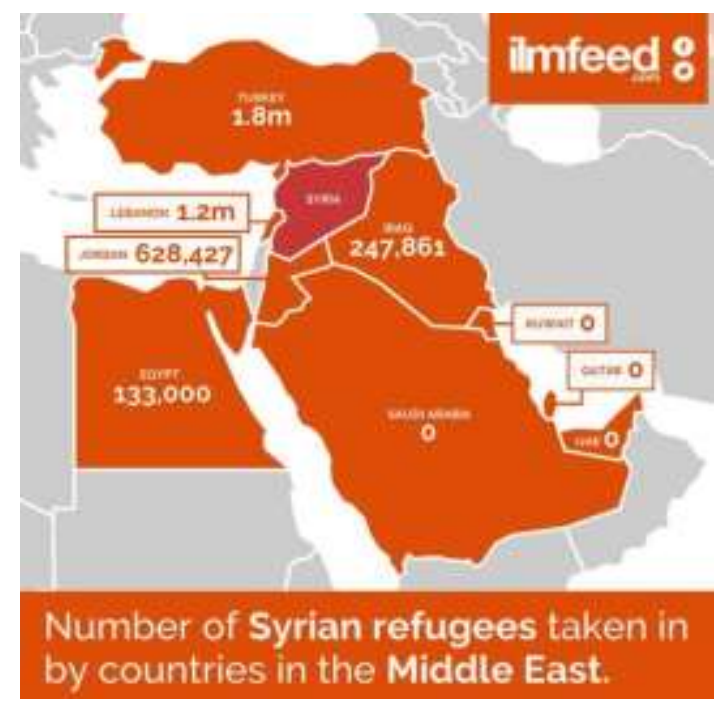

(Ardyan Muhammad: Merdeka.com)

According to an article that we read, the reason why Syrian refugees chose Turkey asdestination is because they think that they would perceive a better life is possible. They think that if they move to Europe, they won't get a better life like what they get in Turkey. This reason is valid based on a series of interviews conducted with Syrian refugees. They were using their socioeconomic resources to facilitate integration. When they did travel di Europe, they found that life in Europe was not as they anticipated. Also many Syrians stated that they don't desire ti go to Europe because they said that Europeans have more negative attitudes than Turks towards refugees. According to an interview session with one of the Syrian refugees, they said that 
Europeans tend to have an "image" for the refugees and they think that refugees are flom a different planet and they are not welcoming the refugees. Moreover, in Germany they had protests against accepting refugees. (Simpson, 2017).

Another reason why the Syrian refugees tend to choose Turkey as their destination and feel comfortable in Turkey, is that when they step outside to the streets, people in Turkey don't look at the refugees differently. They look at the refugees like their own brother or like the citizen of Turkey itself. Before going for a migration, Syrian refugees communicate with Syrians in Turkey via Facebook, Skype or Whatsapp first about the experiences or further information. We think this is why they tend to choose Turkey to stay in rather than Europe. (Balcioglu, 2017).

Based on the interviews conducted with Syrian refugees, we can conclude that the top three reason why refugees tend to choose Turkey as destination is because Turkey is safe, appealing socio-economic conditions, and ease of access to asylum procedures. (Ankara, 2018).

\section{Turkey's Action in Accepting Syrian Refugees}

Since Turkey now is a host of the largest refugees population in the world, Government of Turkey took some action regarding to the high number of refugees coming in to Turkey. The first step that taken by the government is by making a noncamp approach by only $12 \%$ of the total number of Syrian refugees are living in tents and temporary shelters, while some of the number settled in urban areas, where they already can seek for their own income and work opportunities. The second step taken by the government is by a government-financed approach program. The government already spent approximately about $\$ 7.6$ billion by September 2015 in response to Syrian refugees.(Bank, 1956). Because of the increasing amount of refugees coming to Turkey, and limitations of shelters, the government of Turkey directs refugees into camps supported by humanitarian agencies. The government think that if the refugees are supported in becoming socially and economically self-reliant, and give freedoom of movement and protection, the refugees more likely to contribute economically to their host country.

Besides the government, the actions involves many acts of individual kindness at the local level, like Turkish families and civil society organizations also helped by 
making donations and extended help to their Syrian neighbors. According to a survey conducted by HUGO in 2014, across a large sample in 18 provinces indicated that $31 \%$ of Turkish respondents had made a personal financial contribution to support the Syrian refugees. By this matter the Turkey government made a policy called Temporary Protection. And in this policy Syrian refugees guaranteed access to health care, education, social service, and the labor market. Besides that, psychosocial support and rehabilitation services are also prioritized for those who with special needs, such as children, women, and elders.(Bank, 1956)

Many efforts has done by the Government of Turkey, for example the government of Turkey has increasingly involved international organizations and civil society groups with experience in protracted refugee response settings, like in 2015 the UNHCR cooperated close to the Government of Turkey to develop a new asylum system. Some community-based and NGOS also provided invaluable local-level support for the refugees, it is included setting up community centers and offering legal advices, translation services, etc. In the camp system itself, the government made 25 camps across 10 provinces in Turkey and the camps are all managed and financed by Turkey through AFAD (Disaster and Emergency Management Presidency) and AFAD utilized UNHCR camp guidelines. During the first waves of Syrians refugee came to Turkey, the government had set up an emergency camp for the refugees in southern Hatay Province. Then in less than four years, Government of Turkey has shouldered the financial and management responsibility of 25 camps. The camps aimed to offer a better standard of shelter and services and have been recognized for its cleanliness, safety, and maintance.(Bank, 1956).

Turkish's NGO, AFAD also established a Disaster Management System (AFKEN). This system allows the camps to be managed, standardized, and monitored in one holistic system. Through this system the government of Turkey can monitor the capacity status of the camps and manage aid distributions.(Bank, 1956).

\section{The Advantages of Turkey Government in Accepting Syrian Refugees}

The are several reasons why Turkey implementing the open-door policy in accepting the refugees from Syria. In theory according to Machiavelli the state will always seeking for the national interest in producing some public policy. In the other 
side, according to Robert Cox theory will always for someone and some purpose (Cox, 1981). However, it relates with the policy which Turkey implementing toward the refugees of course there is will always some purpose and for some interest behind which become the factor which drive the Ankara administration. Furthermore, in current condition the President Erdogan faced a lot of protest and complaint form the Turkey society because the refugees nowadays become one of the challenge to the native Turkey especially in the capital city of Turkey which the native and refugees often competing in term of economic, culture and etc. furthermore, because of those problems it creating new conflict in Turkey which because of that the society try to always push the government to bring refugees back to their own country in Syrian where the other side the Syrian refugees are won't to do so (International, SENT TO A WAR ZONE: TURKEY'S ILLEGAL DEPORTATIONS OF SYRIAN REFUGEES , 2019).

Turkey still in progress in term of endeavor to give any space for the Syrian refugees to live. After a long of discussion and the native Turkey aspiration to the government the Ankara administration until nowadays still stick in the same policy to facilitating and give any opportunities for the Syrian refugees (Çorabatır, 2016). Even the condition is not the same anymore as in the very first beginning because the number of the refugees in Turkey was high rapidly until Turkey become the country who has predicate as the highest acceptation refugees in the world roughly 3 million refugees are decided to choose Turkey as the place for them in excepting from the terrible condition in their own country Syria. Then why Turkey can do so in facilitating and treat the refugees from the Syria? What is the reason behind which made Turkey be very take into account of the Syria refugees by implementing the open-door policy to the entire society of Syria even nowadays Turkey still in effort to facilitate the Syria refugees by open save zone near by Syria and Turkey borders for the Syria refugees. However, there some reason behind why Turkey would like to help the Syria refugees based on the Regime theory, the reason behind are 1) Increasing the good name of Turkey nations 2) The refugees become a tool in order to become the members of EU 3) Caring on the Human Right issues and Commitment for the 1951 convention.

The first factors are increasing the good name of Turkey nations. As one of big country in the world which have strategic location in the area between Asia and Europa Turkey have big opportunities to give the bargaining position and show to the world if 
Turkey have big role in term of peace building and others action. However, by this refugee's issue Turkey also use this occasion as a tool of diplomacy to the world to show how care and big role of the Turkey in the area. According to Joseph Nye Disaster can become the opportunities for gaining the Turkey national interest (Joseph S. Nye, 2016).The example because of the refugees cases Turkey can do collaboration with many of stake holder in national level or International level this also based on the regime theory where the NGO can take part in solving the nation problems. Furthermore, the name the Turkey nation become famously as the country who able to accepting a lot of number of refugees it make the EU as one of the institution who caring about this problems also give an aid to Turkey government for help Turkey in facilitating the refugees even the aid is not that enough for a billions refugees in Turkey. The NGO's also contribute a lot in handling the refugee's problems for the example IHH from Turkey and ACT from Indonesia who contribute a lot in empower the Syrian refugees in Turkey. (Dwijayanto, 2019). Finally, because of this action Turkey got a lot of advantages the first Turkey known as philanthropist country, the second Turkey got additional aid from the EU and other IGO and the last Turkey also can collaborate with a lot of NGO's in the world to hand in hand in providing the necessity of the refugees and give the refugees their opportunity and right as the a human because the humanitarian is the vital things that everybody in the world should be take into a count and should be fulfill (Auditors, 2018).

The second advantages that Turkey can get from the refugees is Refugees case can become the ticket for Turkey to become the member of EU (Kurban, 2017). Turkey since a long time ago has registered in order to become the permanent member of EU. Unfortunately, until nowadays Turkey still become the candidate statutes in EU. Because of the Turkey effort a lot of things in order to prepare their country to able to become the members of EU. one of the reasons why Turkey cannot become the members of EU is because Turkey suspected by many of members EU the country who are not humanity in humanitarian issues. By this opportunity Turkey now prove to the all of the world if Turkey become the country who really care and ready for helping the refugees problems in the world especially the refugees issues caused by the conflict in Middle East which a lot members of EU are not willing to accept the refugees into their country. 
The third point is about the humanitarian and the commitment of Turkey in ratifying the 1951 convention (UNHCR, COMMENTARY ON THE REFUGEE CONVENTION 1951 ARTICLES 2-11, 13-37, 1977). However, beside of the national interest of Turkey of course the feeling of the humanitarian will cannot be spread by the human live especially Turkey as one of the country with the most population are Muslim and the victims who become the refugees also coming up from the Muslim countries especially Syria. However, that is also become the fundamental reason why Turkey really want to help the refugees problems even Turkey able to sacrifice to fight with many of Kurdish military based with the negative impact of in economic, military power and etc. according the Regime theory convention can give big influence for the country in term of producing the action and also the foreign policy. because of that Turkey based on the convention 1951 which asking for every single country in the world for ratifying, help and support the refugees wherever refugees are. Because of that Turkey can become on of the role model country which care a lot with the refugee's issue even it also sometime has the national interest behind but at least the soul of the refugees can helped by the horrible condition because of the greedy of the supreme leader of come country.

\section{The Challenges of Turkey Government in Accepting The Refugees}

Turkey dealing with a lot of challenging because of the open-door policy in accepting the refugees for Syria. Even the desire of Turkey to help the refugees are good in term of humanity. Unfortunately, the Ankara administration got a lot of tension inside and outside the Turkey (Kirişci, 2014). From in the very first beginning of Turkey in implementing the Open-door policy in accepting the refugees Turkey dealing with the high cost in order to facilitating the Syrian refugees fortunately because the number of refugees increase rapidly make many of IGO's and NGO's contributed to help Turkey in accommodating the Syrian refugees. The other challenge is the culture problems between the native Turkey and Syrian refugees because of the differences so it's often creating the tension and conflict between both and the government should give any specific regulation toward the refugees and understanding toward the native Turkey to accepting the Syrian refugees. However, because of the refugee's cases which the impact of the open-door policy made the Turkey government should do double job 
because explicitly Turkey government care out toward two citizenship by only one government. The Turkey government should care toward the Syrian society with different culture and habit but also should care about all the problematic which come up from the Turkey own society.

By the open-door policy Turkey do hard work to facilitate the all the society who entering Turkey. Turkey done with a lot of project started from building the health facilities, basecamp, aid, school facilities even place for Syrian refugees work also able to achieve by the Syrian refugees and of course it was tiring and need a lot of attention from Turkey government despite of the reason behind why Turkey government implementing this policy (International, STRUGGLING TO SURVIVE REFUGEES FROM SYRIA IN TURKEY , 2014).

\section{Conclusion}

Refugees issues is become the hot issues in the last decade. The refugee's problems become one of the globe problems which need to be consider for the whole of the society in the world. Become refugees is the condition where the people do not know what should do and with who they must back. The family was disappeared, the relative was gone. Become refugees mean become someone who struggling through this life without money, family and opportunity. Refugees got a lot of dilemmas in continuing their life which sometime there is no single other country who would like to accommodate them and providing their basic need of life. Turkey as one of the countries well known as the highest number in accepting the refugees especially, they are come from Syria. Because Turkey is close by Syria many of the Syrian refugees decided enter to Turkey its also support by the policy which implemented by Ankara administration by the name "'Open-door policy"' which by this policy a millions of refugees are live in Turkey especially also in the capital city of Turkey. The reason behind why Turkey implementing this policy is because of several reasons such as the humanitarian case, as the requirement to entering the EU and to ratifying the convention in 1951 which talking about the refugee's issues. Beside of that Turkey also got a lot of conflict from inside and outside the Turkey because of this policy but Turkey still stick with this commitment in order to help the refugees from Syrian because if Turkey not willing to do this action the condition of the refugees in Middle East especially will do 
not know how to determine their life. However, the case of the refugees is the responsibility for all the society in entire world because to care about the humanity we only need to become the human.

\section{References}

Amalia. (2018). Kebijakan Pintu Terbuka Turki sebagai Upaya Deeskalasi Konflik Suriah. Jurnal Middle East and Islamic Studies.

Ankara. (2018). Migrants and Refugees Increasingly Choosing Turkey as Final Destination. IOM UN immigration.

Auditors, E. C. (2018). The Facility for Refugees in Turkey: Helpful Support, but Improvements Needed to Deliver More Value for Money. Luxemburg : European Union .

Balcioglu, Z. (2017). Syrian Refugees Choose Turkey. Carneige.

Çorabatır, D. D. (2016). Challenges and Opportunities of Refugee Integration in Turkey. Ankara: Research Centre on Asylum and Migration (IGAM) .

Cox, R. W. (1981). Social Forces, States and World Orders: Beyond International Relations Theory. SAGE Journals , 126.

Dwijayanto, A., Fathoni, K., \& Afif, Y. (2019). Diaspora Muslim Rohingya di Indonesia: Minoritas, Militansi dan Pencarian Identitas. El-Wasathiya: Jurnal Studi Agama, 7 (2), 245-263.

Fahham, A. M., \& Kartaatmaja, M. A. (2014). Konflik Suriah Akar Masalah dan Dampaknya . 47.

Huber, C., \& Reid, K. (2014). FAQs: War in Syria, Children, and the Refugee Crisis.

International, A. (2014). Struggling to Survive Refugees from Syria in Turkey . London: Amnesty International .

International, A. (2019). Sent To A War Zone: Turkey's Illegal Deportations of Syrian Refugees. London: Amnesty International.

Joseph S. Nye, J. (2016). Soft Power. Jstor, 154.

Kemlu.go.id. (n.d.). Profil Suriah.

Kibar, E. D. (2013). An Overview and Discussion of The New Turkish Law on Foreigners and International Protection. The Journal Faculty of Political Science Ankara University, 28(3). 
Syrian Refugees in Turkey...

Kirişci, K. (2014). Syrian Refugees and Turkey's Challenges: Going Beyond Hospitality . Washington: Brookings.

Kuncahyono, T. (2013). Musim Semi Suriah : Anak-anak Sekolah Penyulut Revolusi. 115-116.

Kurban, L. H. (2017). Lessons Learnt from the EU-Turkey Refugee Agreement in Guiding EU Migration Partnerships with Origin and Transit Countries. Global Policy, 85 - 86.

Sari, P. M. (2017). Kebijakan Pemerintah Turki terhadap Pengungsi Suriah Era Presiden Recep Tayyip Erdogan (Periode 2015-2016).

Simmons, S. H. (1987). Theories of International Regimes . Harvard University's DASH repository, 493.

Simpson, C. (2017). Syrian Refugees Choose Turkey. Carneige.

Simsek, \& Dogus. (2017). Turkey as a 'Safe Third Country'? The Impacts of the EUTurkey Statement on Syrian Refugees in Turkey. The Journal College of Social Science and Humanities,.

Soekanto, S. S. (2016). Pasca Musim Semi Arab. Jakarta: YLIPP.

Sumaryati , T. (2016). Kebijakan Pemerintah Turki Terhadap Pengungsi di Suriah.

Suri, A. (2019). Motivasi Turki Memutuskan Hubungan Diplomatik Dengan Suriah Pada Masa Pemerintahan Reccep Tayyip Erdogan. JOM FISIP, 11-12.

Syukran, \& Ubaidullah. (2019). Dampak Kebijakan Pintu Terbuka (Open Door Policy) Turki Bagi Pengungsi Suriah Terhadap Kepentingan Nasional Turki Tahun 2011-2016. Jurnal Ilmiah Mahasiswa FISIP Unsyiah.

UNHCR. (1977). Commentary on The Refugee Convention 1951 Articles 2-11, 13-37. Geneva: United Nations .

UNHCR. (2020). Syria Regional Refugee Response.

UNHCR. (n.d.). Operational Portal Refugee Situation. Retrieved from UNHCR: https://data2.unhcr.org/en/situations/syria

USTUN, K. B. (2015). Turkey's Syrian Refugees toward Integration. Ankara: SETA Publications . 